\title{
SARRACENIA JONESII F. VIRIDESCENS: A NEW COMBINATION IN SARRACENIACEAE
}

BARRY A. RICE $\bullet$ Center for Plant Diversity $\bullet$ University of California $\bullet$ One Shields Avenue $\bullet$ Davis - California 95616•USA • bamrice@ucdavis.edu

Keywords: Taxonomy, Sarracenia jonesii f. viridescens.

Received: 18 July 2018

The Sarracenia rubra complex has a long history of differing interpretations. Don Schnell has long held the view that the taxa within this species should all be treated as separate subspecies, i.e.

Sarracenia rubra Walter

Sarracenia rubra subsp. alabamensis (Case \& R.B. Case) McPherson \& D.E.Schnell

Sarracenia rubra subsp. jonesii (Wherry) Wherry

Sarracenia rubra subsp. wherryi (Case \& R.B.Case) D.E.Schnell

Sarracenia rubra subsp. gulfensis D.E.Schnell

His perspectives on this are clearly articulated in his various works (e.g. McPherson \& Schnell 2011; Schnell 2002; and others). An alternative perspective is to treat them as three species:

Sarracenia rubra Walter

Sarracenia rubra subsp. gulfensis D.E.Schnell

Sarracenia rubra subsp. wherryi (Case \& R.B.Case) D.E.Schnell

Sarracenia alabamensis Case \& R.B.Case

Sarracenia jonesii Wherry

This is the perspective that I took in my own book (Rice 2006). However, over time I have been increasingly impressed by how similar Sarracenia alabamensis is to Sarracenia rubra subsp. wherryi. The fact that Sarracenia rubra subsp. wherryi in general occurs (in broad terms) downstream of Sarracenia alabamensis sites is also evocative. As such, over time I have slowly evolved to the following perspective:

Sarracenia rubra Walter

Sarracenia rubra subsp. gulfensis D.E.Schnell

Sarracenia rubra subsp. viatorum B.Rice

Sarracenia alabamensis Case \& R.B.Case

Sarracenia alabamensis subsp. wherryi Case \& R.B.Case

Sarracenia jonesii Wherry

This is the model that I have used for the last several years, mostly in on-line publications such as Rice (2018a). The above list also includes the recently described Sarracenia rubra subsp. viatorum (Rice 2018b).

In McPherson \& Schnell (2011) several new taxa were described, including the anthocyanin-free plant called Sarracenia rubra subsp. jonesii f. viridescens S.McPherson \& D.E.Schnell (see Front Cover). To allow for the discussion of this plant under conceptual frameworks similar to mine, I must create a new combination, i.e.

Sarracenia jonesii f. viridescens (S.McPherson \& D.E.Schnell) B.Rice comb. nov.

This new combination is in direct reference to the basionym: 
Basionym: Sarracenia rubra subsp. jonesii f. viridescens S.McPherson \& D.E.Schnell, Sarraceniaceae of North America: 759 (2011).

\section{References}

McPherson, S., and Schnell, D. 2011. Sarraceniaceae of North America. Redfern Natural History

Productions, Poole, Dorset, England. 810 pp.

Rice, B.A. 2006. Growing Carnivorous Plants. Timber Press, Portland, Oregon. 225 pp.

Rice, B.A. 2018a. Carnivorous Plant FAQ, v12, http://www.sarracenia.com/faq.html, accessed 18 July 2018.

Rice, B.A. 2018b. The long overdue recognition of Sarracenia rubra subsp. viatorum, Carniv. Pl. Newslett. 47(4):152-159.

Schnell, D.E. 2002. Carnivorous Plants of the United States and Canada, 2nd ed. Timber Press, Portland, Oregon. 470 pp.

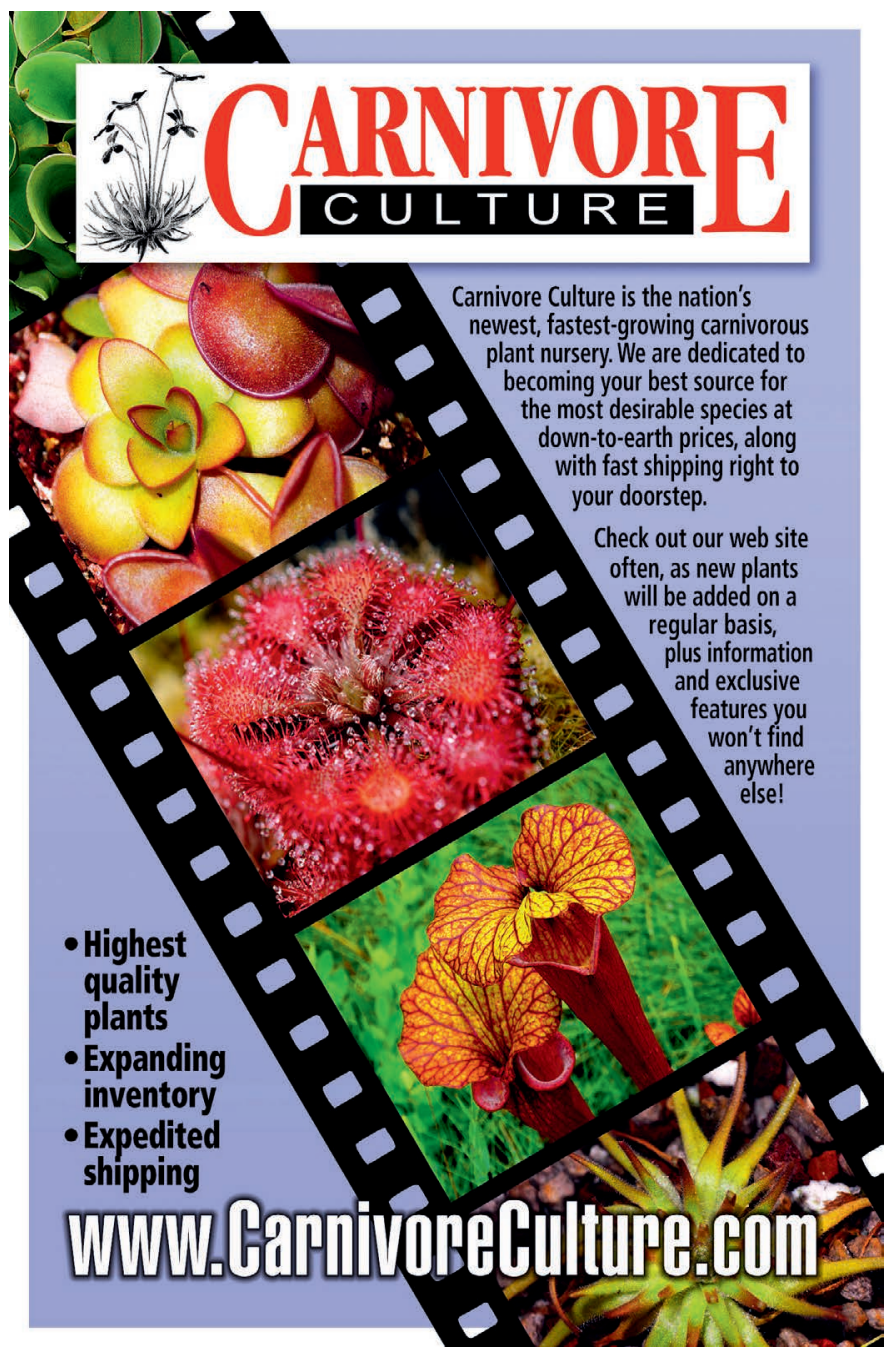




\section{CARNIVOROUS PLANT NEWSLETTER}

Journal of the International Carnivorous Plant Society

Volume 48, No. 1

March 2019 


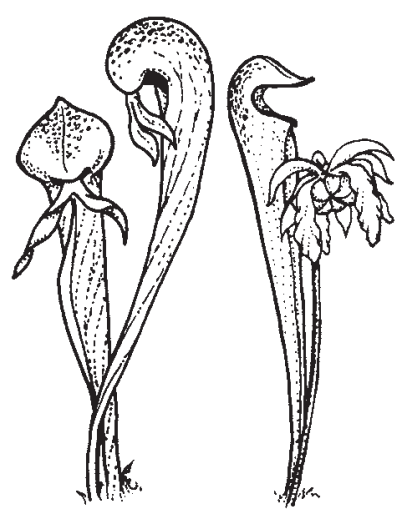

\section{CARNIVOROUS \\ PLANT \\ NEWSLETTER}

Journal of the International

Carnivorous Plant Society

www.carnivorousplants.org

\section{Volume 48, Number 1 March 2019}

Front Cover: Sarracenia jonesii f. viridescens, an anthocyanin free plant from Oxford, Etowah, North Carolina, grown by James Stevens in the UK, originally purchased from Mike King of Shropshire Sarracenias. Article on page 4. Photo by James Stevens.

\section{Back Cover: Meadowview interns Emily Gotschalk (left) and Simret Asgedom (right) in May 2014 at Meadowview headquarters and the National Sarracenia Pitcher Plant Collection. Photo by Meadowview, company archive. Article on page 20.}

Carnivorous Plant Newsletter is dedicated to spreading knowledge and news related to carnivorous plants. Reader contributions are essential for this mission to be successful. Do not hesitate to contact the editors with information about your plants, conservation projects, field trips, or noteworthy events. Advertisers should contact the editors. Views expressed in this publication are those of the authors, not the editorial staff.

All correspondence regarding dues, address changes and missing issues should be sent to the Membership Coordinator at the ICPS. Do not send such correspondence to the editors. Checks for subscriptions should be made to the International Carnivorous Plant Society in US funds. Dues, including a subscription, are \$30 per year.

International Carnivorous Plant Society, Inc.

2121 N. California Blvd., Suite 290

Walnut Creek, CA 94596-7351, USA

icps@carnivorousplants.org

President

Vice President

Secretary

Treasurer

Board Member

Board Member

Board Member

Membership Coordinator

Webmaster

Media Coordinator

Seed Bank Manager

CPN Editors

Managing Editor

Editor

Editor

Editor

Science Editor

Science Editor

Science Editor

\author{
Marcel van den Broek, marcel@carnivorousplants.org \\ Richard Nunn, richardnunn@carnivorousplants.org \\ Keith Becker, keith@carnivorousplants.org \\ Ryan Ward, ryan@carnivorousplants.org \\ Brent Jones, Conservation Director, brent@carnivorousplants.org \\ Jan Schlauer, Cultivar Registrar, jan@carnivorousplants.org \\ Bob Ziemer, bob@carnivorousplants.org \\ Carolyn Becker, carolyn@carnivorousplants.org \\ John Brittnacher, john@carnivorousplants.org \\ ChadWilliams, chad@carnivorousplants.org \\ Joe Griffin, joe@carnivorousplants.org \\ editor@carnivorousplants.org \\ Bob Ziemer \\ Barry Rice \\ Karl Herold \\ John Brittnacher \\ Andreas Fleischmann \\ Fernando Rivadavia \\ Jan Schlauer
}

Date of effective publication of the December 2018 issue of Carnivorous Plant Newsletter: November 52018.

The ICPS is the International Cultivar Registration Authority (ICRA) for the names of cultivated carnivorous plants according to the International Code of Nomenclature for Cultivated Plants. Send relevant correspondence to the ICPS, Inc.

Carnivorous Plant Newsletter is published quarterly in March, June, September, and December by the ICPS, Inc., 2121 N. California Blvd., Suite 290, Walnut Creek, CA 94596, USA. Periodicals postage paid at Walnut Creek, CA and additional mailing offices. Postmaster: Send address changes to ICPS, Inc., 2121 N. California Blvd., Suite 290, Walnut Creek, CA 94596, USA. Printed by Allen Press, Inc., 810 E. 10th Street, Lawrence, KS 66044. Logo and masthead art: Paul Milauskas. (C) 2019 International Carnivorous Plant Society. All rights reserved. ISSN \#0190-9215 